\title{
乱流混合層における変動全圧・速度の同時計測
}

\section{Simultaneous measurement of fluctuating total pressure and velocity in a turbulent mixing layer}

\author{
$\bigcirc$ 正 中 吉嗣 (慶大院) 正 小尾 晋之介 (慶大理工)
}

Yoshitsugu NAKA, Keio University, 3-14-1 Hiyoshi, Yokohama 223-8522
Shinnosuke OBI, Keio University, 3-14-1 Hiyoshi, Yokohama 223-8522

A novel technique to evaluate velocity-pressure correlation is proposed. Static pressure fluctuation is indirectly calculated from fluctuating total and dynamic pressure. The applicability is examined by the measurement in a turbulent mixing layer as well as in a wake of circular cylinder. The result is compared with directly measured fluctuating static pressure. Several statistical procedures are introduced to improve the estimated fluctuating static pressure, and it is confirmed that the correction practices is partly effective. Estimated velocity-pressure correlation with the correction practice has a similar profile to directly measured one. To obtain the quantitatively reasonable data, however, further improvement is still necessary.

Key Words: measurement technique, velocity-pressure correlation

\section{1 緒論}

乱流中の圧力変動は速度変動と同様に乱流を特徵つける重要 なパラメータであり、速度の測定と同様に変動圧力測定の重要 性は認識されていたが、乱流中の压力変動を正確に测定するこ とは難しいとされてきた。これまでに提案された变動圧力を测 定するための手法の中で、向濱ら ${ }^{(1)}$ が提案した小型変動静圧プ ローブは、噴流での測定によってその有効性が検訨され、様々 な乱流場に広く適用可能であることが示された。近年、同型の プローブを用いた変動圧力测定例が複数報告されており ${ }^{(2-6)}$ 、 乱流中の変動圧力測定が可能であることが確かめられつつある。

筆者ら ${ }^{(7)}$ は過去の研究において、向瀆ら ${ }^{(1)}$ と同型の変動 静压測定プローブとX 型熱線流速計を組み合わせ、乱流混合層 の発達領域において速度・圧力相関の分布を測定した。その分布 から見積もった压力拡散項は、自己保存領域においては Rogers

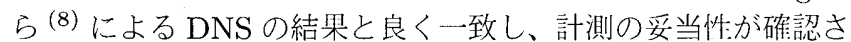
れた。しかし、この方法では圧力プローブの挿人により静压孔 付近の流れが変化することは避けられず、变動速度の测定点を 静圧孔から圧力プローブの影響が及ばない程度に離れた位置に 設定する必要がある。この点が、測定に必要な空間解像度を達 成する上で課題となっていた。

本研究では、変動速度・圧力の同時测定における空間解像度 の問題を解決するために、変動全圧と速度を同時測定し、その 結果から変動静圧の時系列信号を得る手法を採用する。同様の 試みはすでに行われているが (9-11)、本研究では速度・压力の 同時計測に際して高い空間解像度が達成されるよう特に留意す る。変動静圧測定で得られた知見を生かし、速度・压力の同時 测定手法の様々な乱流場への適用性ををらに広げることを目的 として本手法の評価を行う。

\section{2 測定原理}

本研究では変動静圧の時系列信号を得るために、以下の関係 を用いた。

$$
\hat{p}_{t}=\hat{p}+\frac{1}{2} \rho \hat{u}^{2}
$$

ここで、 $\hat{p}_{t}$ は瞬時全圧、 $\hat{p}, \hat{u}$ はそれぞれ瞬時静压、瞬時速度で ある。また、 $\rho$ は流休密度を表亦。本研究では微少な变動压力
を正確に测定するため、圧力センサとしてコンデンサマイクロ フォン用いた。コンデンサマイクロフォンは変動成分のみを測 定可能であるため、式 (1) にレイノルズ分解を施し、全圧、動 圧、静压の変動成分に関する関係式を導出した。

$$
p_{t}=p+\frac{1}{2} \rho\left(2 U u+u^{2}-\overline{u^{2}}\right)
$$

ここで、 $p_{t}, p$ はそれぞれ、変動全圧、変動静压、 $u$ は変動速度、 $U$ は時間平均速度である。実際の変動静圧の計算には、この式 (2)を用いた。

\section{3 実験方法・装置}

本研究では、筆者ら (7) による過去の報告と同様の乱流混合 層風洞、速度・压力测定系を用いた。乱流混合層風洞の流人条件 は表 1 のとおりである。坐標系はスプリッタープレート後縁中 心部を原点とし、流れ方向に $x$ 軸をとり、これに直交し低速側 から高速側へ向かう方向を正として $y$ 軸を定義した。 $z$ 軸は $x$, $y$ 軸に直交するよう、右手系で定義した。測定は $x=100 \mathrm{~mm}$ 、 $-25.2 \mathrm{~mm} \leq y \leq 25.2 \mathrm{~mm}$ で行った。サンプリングレートは $10 \mathrm{kHz}$ 、サンプル時間を 400 秒とした。

今回製作した全圧プローブの概要を図 1 に示す。高い空間 解像度を達成するため、以径 $0.4 \mathrm{~mm}$, 外径 $0.5 \mathrm{~mm}$ のパイプを 用い、これをコンデンサマイクロフォンとのジョイント部分に 接合した。

変動全圧・速度の同時計測に先だって、変動全圧測定系の 検定を行った。全王プローブの角度特性、压力測定系の周波 数応答、速度・圧力プローブの相互丁渉の影響を調べた。こ れらの計測系の基本的な特性に関しては、別稿(12)で報告し たため、ここではその影響について概略を述べるにとどめる。 今回用いた変動全压プローブの的度特性について、圧力係数 $C p=\left(P_{t}(\alpha)-P_{t}(0)\right) / P_{t}(0)$ を評価したところ、流れの迎え向 が土15以内であれば、それに伴う誤差が $1 \%$ 以内であることを 確認した。

本手法を用いて間接的に求められる変動静圧は、変動全圧と 変動動压の信号間の時間遜れに大きく影響を受ける。変動全圧 信号の時間遅れの原因として、主に以下の 3 つが考えられる。 


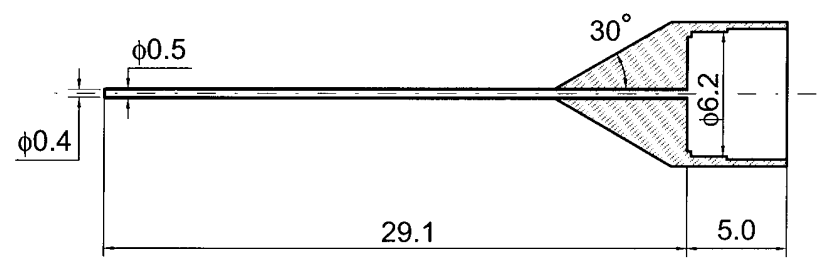

Fig. 1: Schematic of the total pressure probe (dimensions in $\mathrm{mm}$ ).

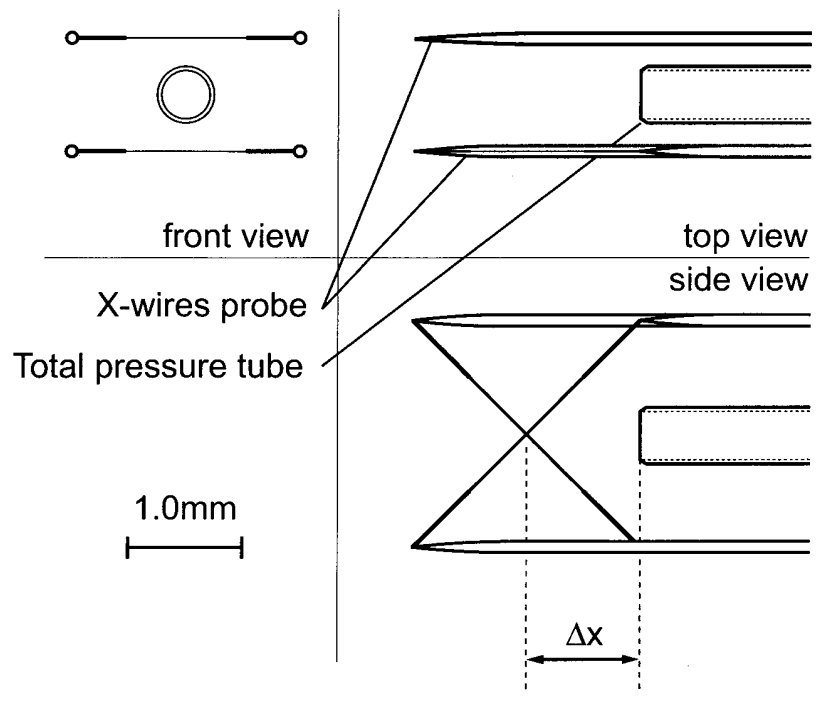

Fig. 2: Arrangement of the total pressure probe and the $\mathrm{X}$-wires hot-wire probe.

・コンデンサマイクロフォンの電気回路応答

- 全圧プローブ以部の気柱共鳴、ヘルムホルツ共振

・速度センサと压力センサの距離に起因した時間遅れ

これらの原因によって変動圧力信号に生ずる位相差については ポスト処理によって除去した。その詳しい手順は別稿 ${ }^{(12)}$ に示 した。

変動全圧プローブとX 型熱線センサは図 2 に示したように 2 本の熱線センサの中央と全压管の中心軸が一致するように配 置した。 $x$ 軸方向に関しては、プローブ間距離 $\Delta x$ を $\mathrm{X}$ 型熱線 センサの交点から全压管の先端までの距離と定義し、速度の平 均值・変動値に全圧管の近接の影響が無いようなプロープ間距 離を $\Delta x=2 \mathrm{~mm}$ と決定した。

本測定における空間解像度は、コルモゴロフスケール $\eta_{K} に$ 対して全压管内径は $6 \eta_{K} 、 \mathrm{X}$ 型熱線流速計のセンサ間距離は $15 \eta_{K}$ であった。また、本测定で採用したプローブ間距離 $\Delta x$ は $30 \eta_{K}$ に相当する。ここで $\eta_{K}$ は混合層中心における熱線流速 計の測定結果から、局所等方性の仮定とテイラーの凍結性仮説 を適用して見積もった。

\section{4 円柱後流における測定}

変動压力測定の妥当性を確認するため、乱流混合層での测 定に先市って円柱後流に生じるカルマン渦を測定した。図 3 に 示すとおり、円柱の直径 $d_{c}=20 \mathrm{~mm}$, 測定位置は $H=1.25 d_{c}$, $L=1.5 d_{c}$ とした。主流速度 $U_{\infty}=6.78 \mathrm{~m} / \mathrm{s}$, 変動生力・速度 から推定したカルマン渦周期 $f_{c}=70 \mathrm{~Hz}$ であった。これらのパ ラメータから見積もったストローハル数は 0.206 であった。

変動全压・速度の同時测定と変動静压・速度の同時測定を別々 に行った。ここで、静圧プローブで測定した変動静圧を $p_{m}$, 式
Tab. 1: Inlet conditions

\begin{tabular}{c|ccccc}
\hline \hline & $U[\mathrm{~m} / \mathrm{s}]$ & $\mathrm{Tu}_{f}[\%]$ & $\theta_{b}[\mathrm{~mm}]$ & $R e$ & $H$ \\
\hline HSS & 6.78 & 0.86 & 0.88 & 398 & 1.41 \\
LSS & 3.52 & 1.03 & 1.41 & 330 & 1.69 \\
\hline \hline
\end{tabular}

Tab. 2: Statistics in the wake of a circular cylinder

\begin{tabular}{c|ccc}
\hline & $p_{m}$ & $p_{e}$ & $p_{e s}$ \\
\hline RMS & 0.0611 & 0.0772 & 0.0536 \\
Skewness & -0.0336 & -0.5237 & -0.0619 \\
Kurtosis & 2.8748 & 6.2265 & 3.0481 \\
$\overline{u p}$ & $-2.46 \times 10^{-3}$ & $-4.22 \times 10^{-3}$ & $-4.22 \times 10^{-3}$ \\
$\overline{v p}$ & $-4.45 \times 10^{-3}$ & $-2.79 \times 10^{-3}$ & $-1.24 \times 10^{-3}$ \\
\hline \hline
\end{tabular}
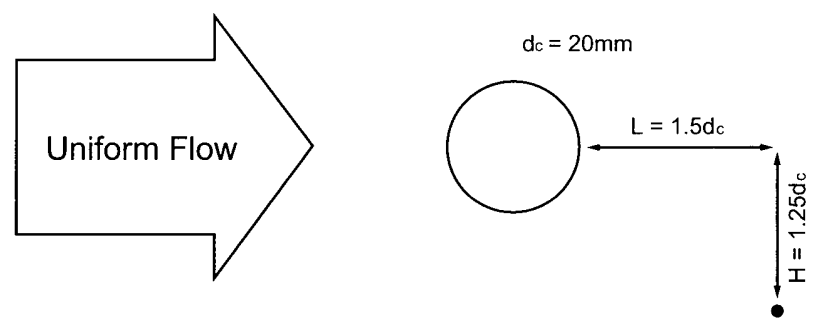

Fig. 3: Schematic of the flow around a circular cylinder.

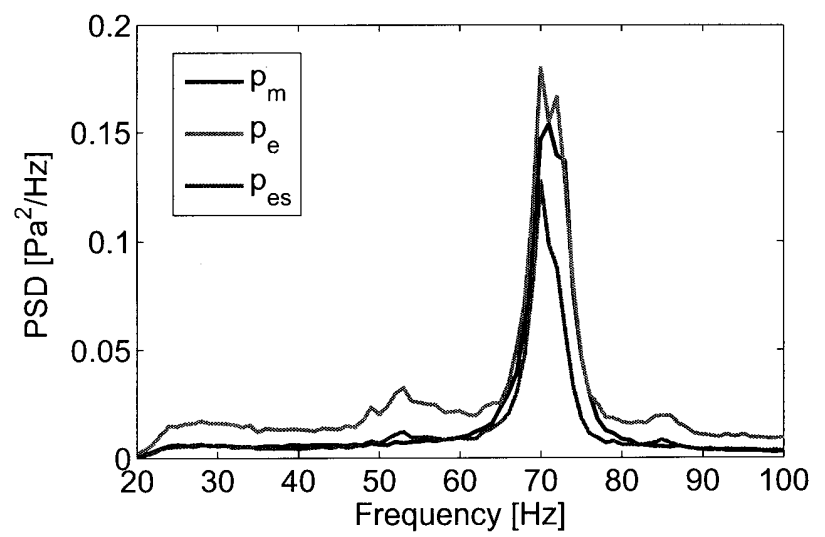

Fig. 4: PSD of fluctuating static pressure.

(2) を用いて変動全圧と变動動圧から求めた变動静压を $p_{e}$ とす る。また、変動全压と変動動压をそれぞれフーリエ変換し、振 れ幅についての差を計算した後、これを逆フーリエ変換するこ とで得られる静圧を $p_{\text {es }}$ とする。逆フーリエ変換の際に必要な 位相の情報は、变動動圧のものをそのまま採用した。変動静圧 $\overline{p_{m}}, \overline{p_{e}}, \overline{p_{e s}}$ のパワースペクトルを図 4 に示市。 $p_{m}, p_{e}, p_{e s}$ の ピーク周波数はほぼ一致しているが、 $\bar{p}$ の分布は渦放出周波数 以外の周波数における值が $\overline{p_{m}}, \overline{p_{e s}}$ の 2 倍程度となっている。

次に、変動静圧の RMS, Skewness, Kurtosis, $\overline{u p}, \overline{v p}$ を表 2 に示す。速度は主流速度 $U_{\infty}$, 圧力は $\frac{1}{2} \rho U_{\infty}{ }^{2}$ を用いて無次元化 


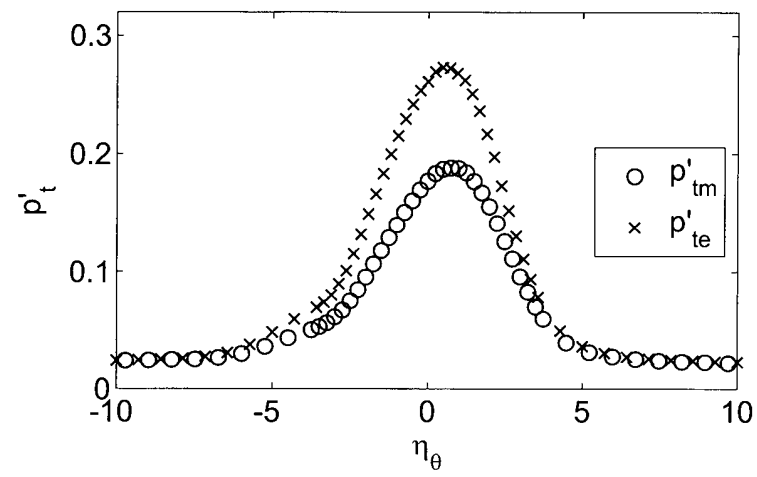

Fig. 5: RMS values of the fluctuating total pressure.

した。 $\overline{u p_{e s}}, \overline{v p_{e s}}$ に関して、 $p_{e s}$ を求める際に行った操作によっ て時間の情報は失われるため、 $p_{\text {es }}$ と速度の相関を直接計算す ることはできない。そこで、 $\overline{u p_{e}}=\overline{u p_{t m}}-\overline{u p_{d}}$ として、 $\overline{u p_{t m}}$ と $\overline{u p_{d}}$ について上と同様の手順で $\overline{u p_{e s}}$ を推定した。 $\overline{v p_{e s}}$ に関 しても同様に推定した。

$p_{m}, p_{e}, p_{e s}$ の統計量を比較すると、 $p_{e}$ の Skewness, Kurtosis は $p_{m}$ と比べてかなり大きい。一方で $p_{e s}$ の RMS, Skewness, Kurtosis は $p_{m}$ の值に近い結果となった。パワースペクトルや 種々の統計量から判断して、 $p_{e}$ がノイズを多く含むような結果 となったのは、全压と動圧の時系列信号に仔在する波形の奀み の影響であろうと考えられる。一方で $p_{e s}$ に関しては、瞬間的 な波形の奀みが周波数空間で統計的に処理されるため、その影 響が小さくなったと考えられる。速度・圧力相関に関して、今 回の結果から定量的な評価はできないが、符号と值のオーダー に関しては一致したので、变動全圧・速度から速度・圧力相関 を見稓もる手法に関して一定の指針を得たと言える。

\section{5 結果}

乱流混合層における変動全圧・速度の同時測定結果について 述べる。比較のため、別途変動静圧・速度の同時测定を行った。 今回の測定位置 $x=100 \mathrm{~mm}$ では、平均速度・レイノルズ応力の 分布形状はほぼ白已保存性を達成していることが確認されてい る(7)(12)。

変動全圧の RMS 值を図 5 に示す。直接測定した変動全圧を $p_{t m}$ 、変動静圧と速度の同時測定結果から式 (2) の関係を用い て見積もった変動全圧を $p_{t e}$ とする。これらの変動全压の RMS 值の分布を比較すると、 $p_{t m}$ は $p_{t e}$ よりも明らかに小さく、混 合層中心で $p_{t m}$ は $p_{t e}$ の $66 \%$ 程度であった。この差の原因が、 直接測定した全圧变動の振れ幅が真の值よりも小さいためであ るならば、直接測定した变動全圧に含まれる変動動压成分と、 速度から見積もった変動動圧が釣り合わず、これらを差し引い て得られる変動静圧に変動動压の成分が残ることが懸念される。 そこで、以下のように定義される変動圧力係数 $\Gamma$ を定義し、 $\Gamma$ 倍した変動全圧を用いて変動静圧を見積もった。

$$
\Gamma=\frac{\sqrt{\overline{\left(p_{m}+p_{d}\right)^{2}}}}{\sqrt{\overline{p_{t m}^{2}}}}
$$

ここで、 $p_{m} 、 p_{d}$ はそれぞれ直接測定した変動静压、変動動圧、 $p_{t m}$ は直接測定した変動全圧である。

静圧変動の RMS 值の分布を図 6 に示寸。変動静圧プローブ を用いて直接測定したものを $p_{m}$ 、全生測定の結果から見積もっ た変動静圧を $p_{e}$ とする。また、式 (3) で定義した変動圧力係数

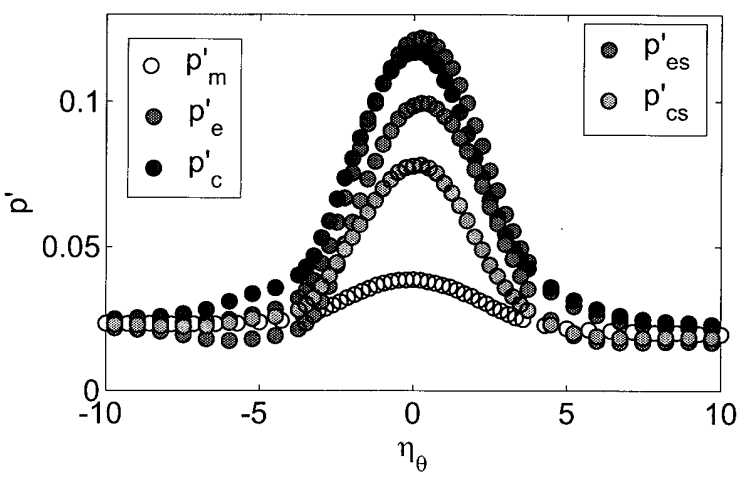

Fig. 6: RMS values of the fluctuating static pressure.

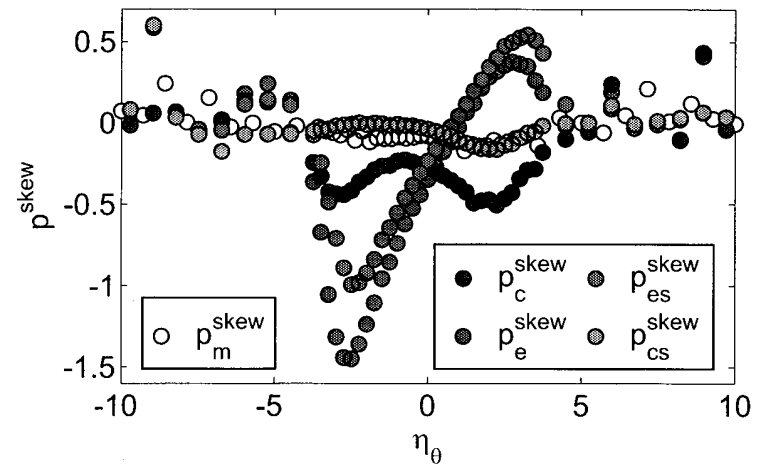

Fig. 7: Skewness of the fluctuating static pressure.

「を用いて補正した全压を用いて見積もった変動静圧を $p_{\mathrm{c}}$ とす る $\left(p_{c}=\Gamma p_{t}-p_{d}\right)$ 。また、円柱後流にお打る測定結果に対して 行ったのと同じように、式 2 の計算を周波数空間で行った結果 として得られる変動圧力を $p_{e s}, p_{c s}$ とする。これらは、それぞ れ $p_{e}, p_{c}$ に対応している。変動静圧の分布形状について $p_{e}$ は $p_{m}$ に比べて相当大きく、混合層中心の值で約 3.1 倍となった。 また、 $p_{c}$ の分布は $p_{e}$ の分布とほとんど变㹱ず、補正の効果 は明らかではない。 $p_{e s}$ と $p_{c s}$ に関して、 $p_{c}, p_{e}$ よりも変動は 小さく、 $p_{c s}$ の最大值は $p_{m}$ の最大值の約 2 倍程度である。

次に、変動静圧の skewness を図 7 に示す。せん断㞗の山で skewness は顀の值を取ることが知られているが、 $p_{e}$ の skewness は $1.2 \leq \eta_{\theta} \leq 3.7$ の領域で正の值を取っている。一方で、 $p_{c}$ の skewness はせん断層中で常に負となり、skewness に関して は補正の効果が認められた。 $p_{e s}$ と $p_{c s}$ の分布は $p_{e}$ と $p_{c}$ とそ れぞれ同じ傾向を示した。定量的には、 $p_{c s}$ の skewness の絶対 值は $p_{c}$ よりも小さく、 $p_{m}$ と同程度であった。

速度・圧力相関 $\overline{u p}, \overline{v p}$ の分布を図 8 に示す。直接測定した $\overline{u p_{m}}, \overline{v p_{m}}$ は原点について対象をとっているが、 $\overline{u p_{e}}, \overline{v p_{e}}$ に関 しては、どちらもせん断層中心でピークを取るような分布をし ている。一方、補正した変動全压から得た $\overline{u p_{c}}, \overline{v p_{c}}$ に関しては、 $\overline{u p_{e}}, \overline{v p_{e}}$ と比較して、定性的に $\overline{u p_{m}}, \overline{v p_{m}}$ により近い分布形状 となった。特に $\overline{v p}$ に関しては $\overline{v p_{m}}$ と同様にせん断層を横切る 間に増減を繰り返方分布で、定量的にも近い値を取っている。

このことから、「による補正によって、全圧と動圧のアン バランスが幾分解消されたと言える。しかし、本研究で変動全 压から見積もった変動静圧には、全圧管で測定した変動全圧に 含まれる变動動圧成分と、熱線流速計で測定した速度から見皟 もった変動動圧のアンバランスによって動圧の成分が残ってい ると考えられ、このアンバランスを解消することが今後の課題 

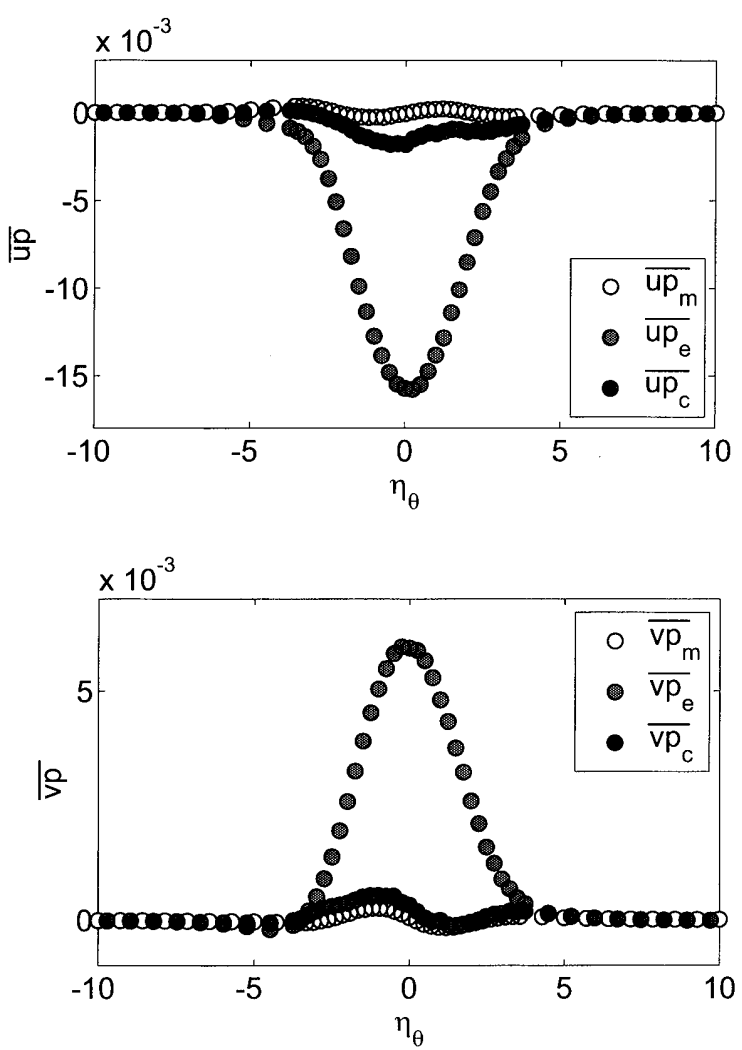

Fig. 8: Velocity-pressure correlation: $\overline{u p_{m}}, \overline{u p_{e}}$ and $\overline{u p_{c}}$ (top); $\overline{v p_{m}}, \overline{v p_{e}}$ and $\overline{v p_{c}}$ (bottom)

である。また、見積もった変動静圧や速度・圧力相関について 定量的な議論を行うには、全圧・動圧測定に含まれる不確かさ について詳しく調べる必要がある。

\section{6 結論}

本研究では、速度・圧力の同時測定の空間解像度を改善する ために新たな測定方法を提案し、その評価を行った。得られた 結論は以下の通りである。

- 変動速度・全圧の同時測定系を構築し基本的な性能の恰定 結果を示した。

- 円柱後流において变動全圧・速度の同時測定を行い、変動 静圧を得た。結果を直接湘定した変動静圧と比較して、本 手法の有效性を確認した。

- 直接測定した変動全圧は、ピーク値で比較して変動静圧と 動圧から見積もった値の $66 \%$ 程度であった。

- 変動全压の值を変動圧力係数 $\Gamma$ を用いて補正したところ、 得られる变動静圧の統計的性:質は直接测定した結果に近づ けることができた。

- 速度・压力相関 $\overline{u p_{e}}, \overline{v p_{e}}$ の分布は $\overline{u p_{m}}, \overline{v p_{m}}$ と定性的に も異なる結果となったが、変動圧力係数 $\Gamma$ を用いて変動全 圧の振れ幅を補正することで、分布の定性的な傾向は直接 測定したものに近づけることができた。

\section{7 謝辞}

本研究の一部は、日本学術振興会 科学研究費補助金 特別研 究員奖励費（課題番号 19.5711）による補助のもとで行わ扎た。
参考文献

(1) 白溑 芳朗, 豊田 国昭, 1993, “変動圧力測定プローブの開 発”, 日本機械学会論文集 $B, 59-567,3381-3387$.

(2) Tsuji, Y. and Ishihara, T., 2003, "Similarity scaling of pressure fluctuation in turbulence", Phys. Rev. E, 68, 026309

(3) Tsuji, Y., Fransson, J. H. M., Alfredsson, P. H., and Johansson, A. V., 2007, "Pressure statistics and their scaling in high-Reynolds-number turbulent boundary layers", J. Fluid Mech., 585, 1-40.

（4）过 義之, 今飯川 純, 阿部 浩幸, 2006, “乱流中の変動圧力の 計測について”，日本機会学会論文集 $B, 72-719,1710-1717$.

（5）飯四明由, 加藤千幸, 大田黑 俊夫, 下出 新一, 1998, “静 圧変動計測による空力音源解析”, 日本機械学会論文集 $B$, 64-623, 2057-2065.

(6) 酒井康彦, 森口 優, 四中伸彦, 山本 睦, 久保 貴, 長网考 二, 2006, “二次元乱流噴流の速度・圧力場の特性に関する 研究”, 日本機械学会論文集 $B, 72-724,2948-2954$.

(7) Naka, Y., Omori, T., Obi, S. and Masuda, S., 2006, "Simultaneous measurements of fluctuating velocity and pressure in a turbulent mixing layer" Int. J. Heat and Fluid Flow, 27, 737-746.

(8) Rogers, M. M., Moser, R. D., 1994, "Direct simulation of a self similar turbulent mixing layer", Phys. Fluids, 6 (2), 903-922.

(9) Komerath, N. M., Hegde, U. G. and Strahle, W. C., 1983. "Turbulent static pressure fluctuations away from flow boundaries" AIAA Journal, 23-9, 1320-.

(10) Giovanangeli, J.-P., 1988, "A new method for measuring static pressure fluctuations with application to wind-wave interaction" Experiments in Fluids, 6, 156164.

(11) Nasseri, M. and Nitsche, W., 1991, "A Probe for Measuring Pressure Fluctuations in Flows" In Proc. ICIASF '91, Rockville, MD, Oct. 27-31, 1991, 25-33.

(12) Naka, Y. and Obi, S., 2007, "Development of a miniature probe for velocity-pressure correlation measurement" In Proc. TSFP-5, Garching, Germany, August. 